International Journal of Child and Adolescent Resilience

Revue internationale de la résilience des enfants et des adolescents

\title{
Examining Child Maltreatment-Related Investigations of Children from Newcomer and non-Newcomer Households in Ontario, Canada
}

\author{
Emmaline Houston, Anika Ganness, Tara Black and Barbara Fallon
}

Volume 8, Number 1, 2021

URI: https://id.erudit.org/iderudit/1082070ar

DOI: https://doi.org/10.7202/1082070ar

See table of contents

\section{Publisher(s)}

Canada Research Chair in Interpersonal Traumas and Resilience/Chaire de recherche du Canada sur les traumas interpersonnels et la résilience

\section{ISSN}

2292-1761 (digital)

\section{Explore this journal}

Cite this article

Houston, E., Ganness, A., Black, T. \& Fallon, B. (2021). Examining Child Maltreatment-Related Investigations of Children from Newcomer and non-Newcomer Households in Ontario, Canada. International Journal of Child and Adolescent Resilience / Revue internationale de la résilience des enfants et des adolescents, 8(1), 110-123. https://doi.org/10.7202/1082070ar

\section{Article abstract}

Objectives: The study aims to further the understanding of child welfare involvement with Newcomer families in Ontario, Canada in 2018. This study examines a) the rate and characteristics of child maltreatment-related investigations involving Newcomer families and b) differences in child maltreatment-related investigations between Newcomer and non-Newcomer families.

Methods: This study is a secondary data analysis of the Ontario Incidence Study of Reported Child Abuse and Neglect-2018 (OIS-2018). Using Statistics Canada Census Data, the Population-based Disparity Index (PDI) was calculated for Newcomer and non-Newcomer families. Descriptive and bivariate chi-square analyses were conducted to determine characteristics of investigations involving Newcomer and non-Newcomer households.

Results: The PDI of the incidence of maltreatment-related investigations involving children under the age of 15 from Newcomer households versus non-Newcomer households in Ontario in 2018 is 2.48.

Implications: The findings suggest that a child maltreatment-related investigation is more than twice as likely to occur if the investigation involves a child from a Newcomer household, when compared a non-Newcomer household in Ontario. This study demonstrates a need for further collaboration with Newcomer communities and their social service providers to better understand risk factors of child welfare involvement, and to increase protective factors for children from Newcomer families. (c) Emmaline Houston, Anika Ganness, Tara Black, Barbara Fallon, 2021

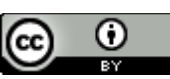

This document is protected by copyright law. Use of the services of Érudit (including reproduction) is subject to its terms and conditions, which can be viewed online.

https://apropos.erudit.org/en/users/policy-on-use/ 


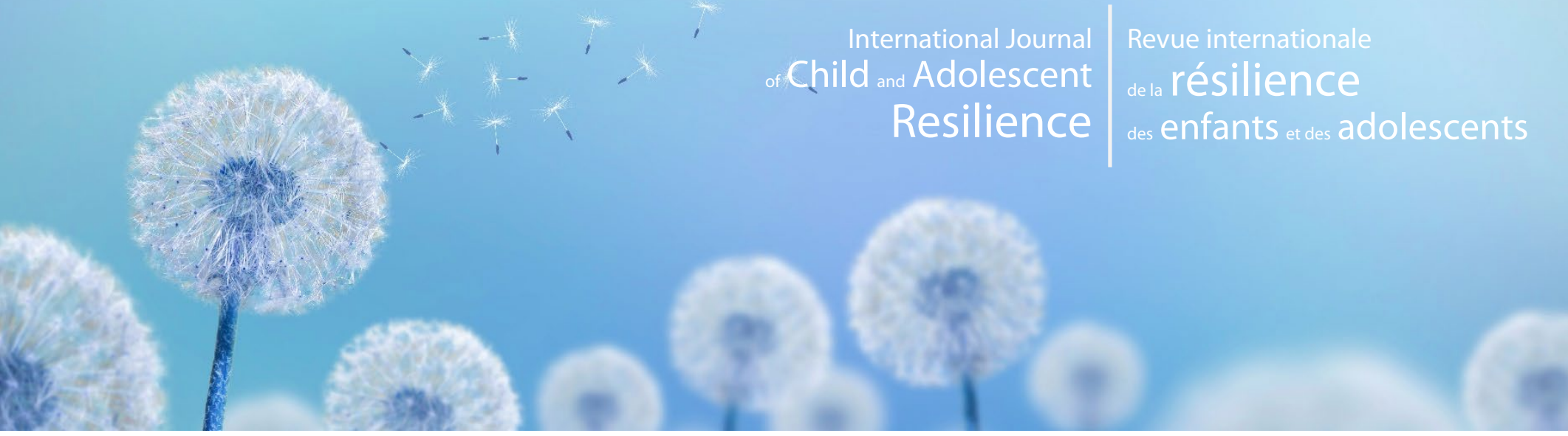

\section{Examining Child Maltreatment-Related Investigations of Children from Newcomer and non-Newcomer Households in Ontario, Canada}

\section{Emmaline HOUSTON', Anika GANNESS', Tara BLACK', and Barbara FALLON'1}

\footnotetext{
1 Factor-Inwentash Faculty of Social Work, University of Toronto, Ontario

2 Department of Political Science, University of Toronto, Ontario

Corresponding Author: Emmaline Houston, 246 Bloor Street W, Toronto, Ontario, M5S 1V4

Email: emmaline.houston@utoronto.ca.
}

\section{Abstract}

Objectives: The study aims to further the understanding of child welfare involvement with Newcomer families in Ontario, Canada in 2018. This study examines a) the rate and characteristics of child maltreatment-related investigations involving Newcomer families and b) differences in child maltreatment-related investigations between Newcomer and non-Newcomer families.

Methods: This study is a secondary data analysis of the Ontario Incidence Study of Reported Child Abuse and Neglect2018 (OIS-2018). Using Statistics Canada Census Data, the Population-based Disparity Index (PDI) was calculated for Newcomer and non-Newcomer families. Descriptive and bivariate chi-square analyses were conducted to determine characteristics of investigations involving Newcomer and non-Newcomer households.

Results: The PDI of the incidence of maltreatment-related investigations involving children under the age of 15 from Newcomer households versus non-Newcomer households in Ontario in 2018 is 2.48.

Implications: The findings suggest that a child maltreatment-related investigation is more than twice as likely to occur if the investigation involves a child from a Newcomer household, when compared a non-Newcomer household in Ontario. This study demonstrates a need for further collaboration with Newcomer communities and their social service providers to better understand risk factors of child welfare involvement, and to increase protective factors for children from Newcomer families.

Keywords: child welfare; child maltreatment; newcomers; immigration. 
Examining Child Maltreatment-Related Investigations of Children

from Newcomer and non-Newcomer Households in Ontario, Canada

\section{Introduction}

In Ontario, Canada, child protection agencies are mandated to "promote the best interests, protection and well-being of children" (CYFSA, 2017). Child protection professionals have a duty to respect the diversity of the children and families they serve, including their race, ethnicity, culture, place of origin, religion, gender, and sexuality (Human Rights Code, 1990; OACAS, 2020). Conversely, studies have identified ethno-racial disparities and disproportionalities within the provincial child welfare system (e.g., Fallon et al., 2015; King et al., 2017; OHRC, 2018; Turner, 2016). Notably, Ontario is home to almost 40\% of Canada's immigrants (Statistics Canada, 2017a). To better understand and meet the needs of children and families who are new to Canada and investigated by the Ontario child welfare system, data specific to the Ontario immigrant population is needed. This study is a secondary data analysis of the Ontario Incidence Study of Reported Child Abuse and Neglect-2018 (OIS-2018), a representative study of reported child abuse and neglect. The rate and characteristics of child maltreatment-related investigations involving children and their families who are new to Canada, and differences in investigations between Newcomer and non-Newcomer families are examined.

Defined by the International Organization for Migration, immigrants are non-nationals who moved and their country of destination becomes their new residence (IOM, 2019). Immigrants', or newcomers', experiences vary widely, encompassing a range from those seeking refugee to those selected to participate in a country's economy (Critelli, 2015; Statistics Canada, 2019). Within this diversity, immigrant families' strengths and needs vary, impacting childrearing practices (Critelli, 2015; Nesteruk \& Marks, 2011; Sakamoto, 2007; Segal \& Mayadas, 2005). Research shows that immigrant families utilize their motivation to cope with adversity, provide for their children, and rely on the strength of family unity as protective factors during the migrant experience (Critelli, 2015; Garcini et al., 2020; Pine \& Drachman, 2005). Many who immigrate also face enormous stresses, ranging from economic (e.g., securing employment) to social (e.g., lack of language proficiency; Critelli, 2015; Segal \& Mayadas, 2005). Through a range of experiences, parents navigate these stresses in addition to bridging various levels of differences between their own cultural parenting practices and norms, both legal and social, of their new home (Nesteruk \& Marks, 2011). These differences may impact involvement with child welfare (Critelli, 2015). For example, a rise in Canadian child welfare investigations has been linked to a recognition of the harmful effects of corporal punishment (Trocmé et al., 2013). The distinction between physical abuse and corporal punishment is not always clear for both professionals and parents (Critelli, 2015; Trocmé et al., 2013). As corporal punishment is used worldwide, the distinction can be especially confusing for immigrant parents (Trocmé et al., 2013). Due to these economic and social stresses, some immigrant children become more vulnerable to maltreatment and require child welfare services (Pine \& Drachman, 2005). However, there is a dearth of understanding of the specific needs of immigrant children and families in the child welfare sector (Earner, 2012; Johnson, 2007; Pine \& Drachman, 2005).

Ontario-based studies have disaggregated data on families who have been investigated by the child protection system for maltreatment-related concerns to analyze disproportionality and disparity by ethno-racial categories (Fallon et al., 2016). Findings from these studies have specifically brought attention to the overrepresentation of Black Canadians and Indigenous populations and underrepresentation of Asian Canadians in child welfare (King et al., 2017; Lee et al., 2016; OHRC, 2018; Trocmé et al., 2004; Turner, 2016). Authors Cénat and colleagues concluded that Ontario graduate schools and child welfare agencies provide "inadequate training on ethnocultural diversity" which contributes to the overrepresentation of Black children in the child welfare system (Cénat, Noorishad et al., 2020). However, what remains unclear is the ethno-racial composition of newcomer families who have been investigated by the Ontario child protection system for maltreatment-related concerns.

In previous studies, newcomers have been defined based on varying inclusion criteria. Studies in North America have defined newcomers based on time since immigration (ranging from 30 months to 10 years) or the proportion of time spent in their home country compared to their current country of residence (Rodriguez, 2019; Stewart et al., 2008; Suárez--Orozco, 2010). These studies examine newcomers as their participant group of interest and demonstrate that there is no universally agreed-upon definition for the newcomer population. However, Statistics Canada defines recent immigrants as being synonymous with newcomers, indicating that newcomers are those who have migrated to Canada and acquired their landed immigrant or permanent resident status within the five-year period proceeding the national census (Statistics Canada, 2010; Statistics Canada, 2017b). According to Census data, 3.5\% of the Canadian population were recent immigrants who had permanently settled in Canada from 2011 to 2016 (Statistics Canada, 2017b). In line with Statistics Canada and for the purposes of comparative research with Census data, the OIS2018 data collection instrument asked the child protection worker to indicate if the caregiver immigrated to Canada 
within five years of data collection. These data were used to define Newcomer ${ }^{1}$ families in our study. Ontario, home to 39\% of Canada's recent immigrants, has the largest immigrant population in the country (Statistics Canada, 2017a), making it a significant province to examine.

\section{Method}

\section{Data Source}

Secondary analyses of data collected in the Ontario Incidence Study of Reported Child Abuse and Neglect2018 (OIS-2018; Fallon et al., 2020) were conducted to meet the objectives of this paper. The OIS-2018 is the sixth provincial study to examine the incidence of child maltreatment-related investigations in Ontario. The OIS-2018 captures information on investigation outcomes, forms and severity of maltreatment, and the characteristics of children and families investigated by child welfare authorities in Ontario (Fallon et al., 2020). Using a multi-stage sampling design, a representative sample of 18 child welfare sites was first selected from 48 child welfare organizations in Ontario in 2018. Next, cases opened in a three-month period from 1 October 2018 to 31 December 2018, within these selected sites, were sampled for inclusion in the OIS-2018 (Fallon et al., 2020). Maltreatment-related investigations that met the inclusion criteria in the OIS-2018 included situations in which there were concerns that a child may have already been abused or neglected (maltreatment investigations), as well as situations in which there was no specific concern about past maltreatment but where the risk of future maltreatment was being assessed (risk investigations). These procedures yielded a final sample of 7,590 child maltreatment-related investigations, and a final weighted estimate of 158,476 child maltreatment-related investigations in Ontario in 2018 (Fallon et al., 2020). Please see Fallon et al. (2020) for a detailed description of weighting procedures to produce the estimates.

Data were collected directly from investigating child welfare workers upon completion of their investigation, based on their clinical judgement and information available to them at the time of completing the study instrument. The OIS-2018 had an item completion rate of over 99\% for all items (Fallon et al., 2020).

\section{Defining Newcomer Household in the Current Study}

In the OIS-2018, data were collected on whether a caregiver moved to Canada within the last five years, based on the worker's clinical judgement and information gathered during the investigation. The Canadian Census data defines children with an immigrant family as the following: "[i]mmigrant family refers to a census family in which at least one spouse or parent is foreign born" (Statistics Canada, 2017a). In following with the Canadian Census definition, for the purposes of this paper, a Newcomer household is defined as any child who resides in a home in which one or both caregivers (i.e., either the primary, secondary or both caregivers) moved to Canada from a foreign country within a five-year period proceeding OIS-2018 data collection. For the current study, the Newcomer variable was derived to match the definition above, using the responses collected from the question "Has this caregiver moved to Canada within the last 5 years?" (Fallon et al., 2020). If the worker selected "yes" for one and/or both caregivers in the home, the investigation was deemed a Newcomer household. If the worker selected "no" for all the caregivers in the home, the investigation was considered a non-Newcomer household. If the worker selected "unknown", they indicated they did not have enough information at the time to confirm if the caregiver moved to Canada within the last five years. Thus, "unknown" data were unable to be placed in either the Newcomer or non-Newcomer households and were not analyzed.

\section{Planned Analyses}

Bivariate Analyses. Descriptive and bivariate chi-square analyses were conducted to determine the characteristics of investigations involving Newcomer households. Chi-square tests of significance were conducted using the sample weight. The sample weight "adjusts for the inflation of the chi-square statistic by the size of the estimate by weighing the estimate down to the original sample size" (Lefebvre et al., 2017, p. 5). Bivariate chi-square analyses were completed on the primary caregiver's primary language, ethno-racial background, and risk factors, as well as the referral source, primary concern of maltreatment, referrals to internal and external services, substantiation, risk of future maltreatment, ongoing services, and placement (please see Table 1 for full study definitions of these variables).

\footnotetext{
1 For the purposes of this paper, when newcomer is lowercase it refers to the community of those who have recently immigrated and when capitalized, Newcomer refers to the subsample analyzed in this study of OIS-2018 data.
} 
Table 1. Variables Collected in the OIS-2018 used in the Present Analyses

\begin{tabular}{|c|c|}
\hline Variable & Definition \\
\hline $\begin{array}{l}\text { Primary Caregiver's Primary } \\
\text { Language }\end{array}$ & $\begin{array}{l}\text { Workers were asked to identify the primary language of the caregiver: English, French, or Other. If Other, please } \\
\text { specify in the space provided. If bilingual, choose the primary language spoken in the home. }\end{array}$ \\
\hline $\begin{array}{l}\text { Primary Caregiver's Ethno- } \\
\text { Racial Background }\end{array}$ & $\begin{array}{l}\text { Workers were asked to endorse the ethno-racial background that best describes the caregiver or select "other" } \\
\text { to identify multiple ethno-racial groups and specify in the space provided. This section used a checklist of ethno- } \\
\text { racial categories used by Statistics Canada in the } 2016 \text { Census (Statistics Canada, 2017d). }\end{array}$ \\
\hline $\begin{array}{l}\text { Primary Caregiver's Risk } \\
\text { Factors }\end{array}$ & $\begin{array}{l}\text { Workers were asked to identify nine risk factors for the primary caregiver (alcohol abuse, drug/solvent abuse, } \\
\text { cognitive impairment, mental health issues, physical health issues, few social supports, victim of intimate partner } \\
\text { violence, perpetrator of intimate partner violence and history of foster/group care). For each risk factor, the } \\
\text { workers were asked to indicate problems that had been "confirmed" (i.e., a diagnosis, directly observed by the } \\
\text { investigating worker or another worker, and/or disclosed by the caregiver), "suspected" (i.e. in their clinical } \\
\text { opinion, "there [was] reason to suspect that the condition may be present, but it has not been diagnosed, } \\
\text { observed, or disclosed"), "no" (i.e. the worker did not believe there was a problem") and "unknown" (i.e. the } \\
\text { worker was "unsure of have not attempted to determine if there was such a caregiver risk factors") (Fallon et al., } \\
\text { 2020, p. 67). The present analyses consider primary caregiver risk factors to be noted if the investigating worker } \\
\text { indicated that these concerns were either "suspected" or "confirmed." }\end{array}$ \\
\hline
\end{tabular}

\section{Referral Source}

\section{Primary Concern of Maltreatment}

\section{Referrals to Internal and External Services}

Substantiation

Risk of Future Maltreatment

Ongoing Services

Placement
Workers were asked to indicate all sources of referral for the case. The referral source variable was derived into three categories: professional, non-professional and anonymous. Professional sources include community, health or social services workers, hospital personnel, school personnel, other child welfare services, day care centre workers, and police (Fallon et al., 2020). Alternatively, non-professional referral sources include people such as a parent, child or relative; while dental or legal service providers are considered other or anonymous referral sources (Fallon et al., 2019).

In maltreatment investigations, workers could identify up to three maltreatment codes that best categorized the reason for the investigation. Only the primary maltreatment code was used for the current analyses. These codes were grouped into five major maltreatment types: physical abuse, sexual abuse, neglect, emotional maltreatment, and children's exposure to intimate partner violence (Fallon et al., 2020). If there wa no alleged incident of maltreatment, the worker would indicate they conducted a risk investigation.

Workers were asked to indicate whether a referral(s) was made for any family member to an internal (provided by at the agency/office) or external service(s) (other agencies/services)

In maltreatment investigations, workers were asked to indicate the level of substantiation for each separate form of investigated maltreatment. The OIS-2018 uses three levels of substantiation: Substantiated: An allegation of maltreatment is considered substantiated if the balance of evidence indicates that abuse or neglect has occurred; Suspected: An allegation of maltreatment is suspected if you do not have enough evidence to substantiate maltreatment, but you also are not sure that maltreatment can be ruled out; Unfounded: An allegation of maltreatment is unfounded if the balance of evidence indicates that abuse or neglect has not occurred.

Based on their clinical judgment, workers were asked to indicate if there was a significant risk of future maltreatment.

Workers were asked to indicate if they planned to, or already had, opened the case to provide ongoing child welfare services.

Workers were asked to indicate whether an out-of-home placement was made during the investigation.

Disproportionality. This study uses rates of incidence or rate per 1,000 children of each group of Newcomer and non-Newcomer identities (using a similar methodology as outlined by Lee et al., 2016) to measure Newcomer representation in the Ontario child welfare system. The formula for the rate per 1,000 child maltreatment-related investigations for Newcomer households in Ontario involved in the child welfare system under the age of 15 years old was calculated by dividing the estimate of child maltreatment-related investigations for Newcomer households by the estimate of Newcomer children in the Census population ${ }^{2}$ and multiplying the results by 1,000 . The formula for the rate per 1,000 child maltreatment-related investigations for Newcomer households in the Ontario population involved in the child welfare system is:

2 The 2016 Census was used for the population-based data. To calculate a comparable rate between the child population in Ontario and the OIS2018 child sample, children less than 15 years old were considered due to available Census demographics on recent immigrants. 


$$
\text { Newcomer rate }=\frac{\text { Rate per 1,000 child maltreatment-related investigations for Newcomer households }}{\text { Census child population of Newcomers households }} \times 1,000
$$

Similarly, the rate per 1,000 child maltreatment-related investigations for non-Newcomer households in Ontario involved in the child welfare system under the age of 15 years old was calculated by dividing the estimate of child maltreatment-related investigations for non-Newcomer households by the estimate of non-Newcomer children in the Census population and multiplying the results by 1,000 to obtain the rate per 1,000. The formula for the rate per 1,000 child maltreatment-related investigations for non-Newcomer households in the Ontario child welfare system is:

$$
\text { Non-Newcomer rate }=\frac{\text { Rate per 1,000 child maltreatment-related investigations for non-Newcomer households }}{\text { Census Child Population of non-Newcomers households }} \times 1,000
$$

Disparity index (DI) is the measure of the difference in the rates of representation in the child welfare service for two groups (Lee et al., 2016), and is often used to compare the ratio of one ethnic or racial group in an event or experience to another ethnic or racial group experiencing the same event (Fluke et al., 2010). DI was used to measure the difference of representation rates in child maltreatment-related investigations for children under the age of 15 years old for Newcomer versus non-Newcomer households in the Ontario child welfare system. The Population-based Disparity Index (PDI) is the rate per 1,000 Newcomer child maltreatment-related investigations in the Ontario population for children from Newcomer households, compared to the rate per 1,000 child maltreatment-related investigations in the Ontario population for children from non-Newcomer households involved in the child welfare system for children under the age of 15 years old. The formula for PDI is the measure of the difference in the rates of representation in the child welfare service of child maltreatment-related investigations for two demographic groups (children from Newcomer versus children from non-Newcomer households). Please see the PDI calculation below:

$$
P D I=\frac{\text { Rate per 1,000 child maltreatment-related investigations for Newcomer households }}{\text { Rate per 1,000 child maltreatment-related investigations for non-Newcomer households }}
$$

\section{Results}

\section{Child Level}

\section{Child Maltreatment-related Investigations} involving Children from Newcomer Households. Table 2 describes the estimates of Newcomer households that were investigated in Ontario by a child welfare agency in 2018. In the current study, 8\% (an estimated 10,591 child maltreatment-related investigations) had at least one caregiver who the worker indicated as a Newcomer to Canada. In $86 \%$ of the child maltreatment-related investigations (an estimated 109,442), the worker indicated that no caregiver(s) had moved to Canada within the last five years. In $4 \%$ of the investigations (an estimated 5,342), the worker was unsure if the caregiver(s) moved to Canada within the last five years. Finally, in $2 \%$ of the child maltreatment-related investigations (an estimated 2,243), no caregiver was investigated as the investigation involved a youth living independently or a community caregiver (e.g., caregiver at day care; Fallon et al., 2020).

Table 2. Estimated Child Maltreatment-Related Investigations ( $<15$ years old) involving Newcomer Households in Ontario in $2018(n=127,617)$

\begin{tabular}{lrr}
\hline Newcomer & \multicolumn{1}{c}{$\#$} & $\%$ \\
\hline At Least One Newcomer Caregiver & 10,591 & 8 \\
No Confirmed Newcomer Caregiver & 109,442 & 86 \\
Unknown Newcomer & 5,342 & 4 \\
Youth Living Independently/ & 2,243 & 2 \\
Community Caregiver & 127,617 & 100 \\
Total &
\end{tabular}

Note. Based on an unweighted sample of 515 Newcomer households, 6,675 non-Newcomer households, 272 Unknown Newcomer households, and 128 Youth Living Independently/Community Caregiver investigations. A Newcomer household for this study is defined in the methods.

Disproportionality. For every 1,000 children in Newcomer households, 133.54 were involved in a child maltreatment-related investigation in the OIS-2018. Please see the calculation below:

$$
\frac{10,591}{79,310} \times 1,000=133.54
$$


For every 1,000 children in non-Newcomer households, 53.78 were involved in a child maltreatment-related investigation in the OIS-2018. Please see the calculation below:

$$
\frac{109,442}{2,034,855} \times 1,000=53.78
$$

Based on our proxy of using Statistics Canada Census Data for Ontario, the Population-based Disparity Index (PDI) of incidence of child maltreatment-related investigations involving children from Newcomer households under the age of 15 years old versus the incidence of child maltreatment-related investigations involving children from nonNewcomer households for children under the age of 15 years old is 2.48. Please see the PDI calculation below:

$$
\frac{133.54}{53.78}=2.48
$$

\section{Caregiver Level}

Primary Language. In Newcomer households, 37\% of primary caregivers investigated for a child maltreatment-related concern spoke English, and 2\% spoke French as their primary language. The majority (61\%) of primary caregivers in Newcomer households spoke a primary language other than English or French. Whereas in only 9\% of investigations in non-Newcomer households, the primary caregiver did not speak English or French as their primary language, 88\% spoke English, and 3\% spoke French.

Ethno-Racial Background. Table 3 shows a disaggregation of the primary caregivers in Newcomer and nonNewcomer households. The ethno-racial backgrounds ${ }^{3}$ of the primary caregivers in Newcomer households that were investigated for maltreatment-related concerns were: Arab (24\%), Black (19\%), White (17\%), South Asian (12\%), Latin American (8\%), Chinese (6\%) and West Asian (5\%) and Southeast Asian (4\%). In non-Newcomer households, the ethnoracial backgrounds of the primary caregivers who were investigated for maltreatment-related concerns were: White (71\%), Black (12\%), South Asian (6\%), Chinese (2\%), Filipino (2\%), Latin American (2\%), and Southeast Asian (2\%). Please see Table 3 for the full results.

Table 3. Primary Caregiver's Ethno-Racial Background in Child Maltreatment-Related Investigations ( $<15$ years old) in

\begin{tabular}{|c|c|c|c|c|c|}
\hline \multirow[b]{2}{*}{ Ethno-Racial Background } & \multicolumn{2}{|c|}{$\begin{array}{l}\text { Newcomer } \\
\text { Households }\end{array}$} & \multicolumn{2}{|c|}{$\begin{array}{l}\text { Non-Newcomer } \\
\text { Households }\end{array}$} & \multirow[b]{2}{*}{$x^{2}$} \\
\hline & $\#$ & $\%$ & $\#$ & $\%$ & \\
\hline White & 1,812 & 17 & 77,582 & 71 & \\
\hline Black & 2,036 & 19 & 12,863 & 12 & \\
\hline Latin American & 803 & 8 & 2,452 & 2 & \\
\hline Arab & 2,542 & 24 & 1,519 & 1 & \\
\hline West Asian (e.g., Iranian, Afghan) & 535 & 5 & 952 & 1 & \\
\hline South Asian (e.g., East Indian, Pakistani, Sri Lankan) & 1,247 & 12 & 6,245 & 6 & \\
\hline Chinese & 655 & 6 & 2,221 & 2 & \\
\hline Southeast Asian (e.g., Vietnamese, Cambodian, Malaysian, Laotian) & 397 & 4 & 1,624 & 2 & \\
\hline Filipino & 200 & 2 & 2,005 & 2 & \\
\hline Japanese & 0 & 0 & - & - & \\
\hline Korean & 116 & 1 & - & - & \\
\hline Other & 247 & 2 & 1,891 & 2 & \\
\hline Total & 10,590 & 100 & 103,565 & 100 & $1146.980^{* * *}$ \\
\hline
\end{tabular}
Ontario in $2018(n=120,033)$

Note. Based on an unweighted sample of 515 Newcomer households and 6,675 non-Newcomer households.

- indicates the estimate was $<100$ caregivers.

${ }^{* * *} p \leq .001$.

Caregiver Risk Factors. As seen in Table 4, at least one risk factor was noted in 56\% of the primary caregivers

${ }^{3}$ Caregivers identified as Indigenous were excluded from this study. The OIS-2018 and authors of this article adhere to the First Nations Principles of Ownership, Control, Access, and Possession (FNIGC, n.d.). The authors of this article did not negotiate the use of First Nations data, and consequently, their data is not included in these analyses. The derived non-Newcomer subsample is defined as caregivers who have been in Canada for five years or longer, as identified by the caseworker. However, the authors acknowledge that the non-Newcomer subsample is operationalized as nonIndigenous caregivers who settled in Canada six years or later by excluding Indigenous caregivers from the analyses. 
in Newcomer households, compared to $54 \%$ in non-Newcomer households; however, this is not a statistically significant difference. The top three noted concerns in Newcomer households were few social supports (41\%), victim of intimate partner violence (30\%), and mental health issues (14\%). Similarly, in non-Newcomer households, the top three noted concerns were victim of intimate partner violence (27\%), mental health issues (24\%) and few social supports (20\%).

Table 4. Primary Caregivers' Risk Factors in Child Maltreatment-Related Investigations ( $<15$ years old) in Ontario in $2018(n=120,033)$

\begin{tabular}{|c|c|c|c|c|c|}
\hline \multirow[b]{2}{*}{ Primary Caregiver Risk Factor } & \multicolumn{2}{|c|}{$\begin{array}{l}\text { Newcomer } \\
\text { Households }\end{array}$} & \multicolumn{2}{|c|}{$\begin{array}{l}\text { Non-Newcomer } \\
\text { Households }\end{array}$} & \multirow[b]{2}{*}{$x^{2}$} \\
\hline & $\#$ & $\%$ & $\#$ & $\%$ & \\
\hline Alcohol abuse & 114 & 1 & 6,699 & 6 & $22.810^{* * * *}$ \\
\hline Drug/solvent abuse & 138 & 1 & 8,131 & 7 & $26.380^{* * * *}$ \\
\hline Cognitive impairment & - & - & 3,681 & 3 & $15.476^{* * *}$ \\
\hline Mental health issues & 1,464 & 14 & 25,917 & 24 & $25.589^{* * *}$ \\
\hline Physical health issues & 277 & 3 & 6,464 & 6 & $9.782^{* *}$ \\
\hline Few social supports & 4,306 & 41 & 21,921 & 20 & $114.903^{* * *}$ \\
\hline Victim of intimate partner violence & 3,206 & 30 & 29,354 & 27 & 2.858 \\
\hline Perpetrator of intimate partner violence & 568 & 5 & 7,699 & 7 & 2.117 \\
\hline History of foster care/group home & - & - & 4,164 & 4 & $15.859^{* * *}$ \\
\hline At least one risk factor & 5,933 & 56 & 58,656 & 54 & 1.088 \\
\hline
\end{tabular}

Note. Based on an unweighted sample of 515 Newcomer households and 6,675 non-Newcomer households.

Rate and percentage columns do not add to totals because investigating workers could identify more than one primary caregiver risk factor.

- indicates the estimate was $<100$ investigations.

${ }^{*} p \leq .05,{ }^{* * *} p \leq .01,{ }^{* * * *} p \leq .001$.

\section{Investigation Level}

Referral Source. Table 5 demonstrates that Newcomer families have a significantly greater proportion of referrals by professional sources than non-Newcomer families (85\% versus 73\%). Children in Newcomer households had a significantly lower proportion of referrals by non-professional sources than children in non-Newcomer homes (10\% versus $24 \%)$. Newcomer families had a greater number of referrals by other/anonymous sources than nonNewcomer families (10\% versus $7 \%)$.

Table 5. Referral Source in Child Maltreatment-Related Investigations ( $<15$ years old) in Ontario $(n=120,033)$

\begin{tabular}{|c|c|c|c|c|c|}
\hline \multirow[b]{2}{*}{ Referral Source } & \multicolumn{2}{|c|}{$\begin{array}{l}\text { Newcomer } \\
\text { Households }\end{array}$} & \multicolumn{2}{|c|}{$\begin{array}{c}\text { Non-Newcomer } \\
\text { Households }\end{array}$} & \multirow[b]{2}{*}{$x^{2}$} \\
\hline & $\#$ & $\%$ & $\#$ & $\%$ & \\
\hline Any Non-Professional Referral Source & 1,038 & 10 & 25,970 & 24 & $51.225^{* * *}$ \\
\hline Any Professional Referral Source & 8,969 & 85 & 79,808 & 73 & $33.034^{* * *}$ \\
\hline Other or Anonymous Referral Source & 1,037 & 10 & 7,608 & 7 & $5.817^{*}$ \\
\hline Total & 10,591 & 105 & 109,441 & 104 & \\
\hline
\end{tabular}

Note. Based on an unweighted sample of 515 Newcomer households and 6,675 non-Newcomer households.

Rate and percentage columns do not add to totals because an investigation could have more than one referral source. ${ }^{*} p \leq .05,{ }^{* * *} p \leq .001$.

Referrals to Internal/External Services. Table 6 outlines the referrals made to internal or external social services for Newcomer households and non-Newcomer households. There was at least one referral made in $40 \%$ of investigations in Newcomer households and 36\% of non-Newcomer households. However, the type of referral varied. In Newcomer households, referrals were made most often to family/parent counselling (48\%), parent education or support (31\%), and intimate partner violence services (25\%). Referrals to cultural services (18\%) and immigration services (10\%) were also made. In non-Newcomer households, referrals were most frequently made to family/parent counselling (42\%), parent education or support (37\%) and psychiatric/mental health services (25\%). There was a statistically significant difference in the proportion of referrals made to intimate partner violence services and 
psychiatric/mental health services.

Table 6. Referrals to Internal or External Services for Any Family Member in Child Maltreatment-Related Investigations $(<15$ years old $)$ in Ontario in $2018(n=120,033)$

\begin{tabular}{|c|c|c|c|c|c|}
\hline \multirow[b]{2}{*}{ Type of Referral } & \multicolumn{2}{|c|}{$\begin{array}{l}\text { Newcomer } \\
\text { Households }\end{array}$} & \multicolumn{2}{|c|}{$\begin{array}{c}\text { Non-Newcomer } \\
\text { Households }\end{array}$} & \multirow[b]{2}{*}{$x^{2}$} \\
\hline & $\#$ & $\%$ & $\#$ & $\%$ & \\
\hline Parent Education or Support & 1,284 & 31 & 14,484 & 37 & 2.270 \\
\hline Family/Parent Counselling & 1,979 & 48 & 16,495 & 42 & 2.782 \\
\hline Drug/Alcohol Counselling/Treatment & 119 & 3 & 3,558 & 9 & $8.271^{* *}$ \\
\hline Psychiatric/Mental Health Services & 443 & 11 & 9,890 & 25 & $20.488^{* * *}$ \\
\hline Intimate Partner Violence Services & 1,054 & 25 & 7,427 & 19 & $4.861^{*}$ \\
\hline Welfare/Social Assistance & 209 & 5 & 741 & 2 & $8.318^{* *}$ \\
\hline Food Bank & 414 & 10 & 1,483 & 4 & $17.292^{* * *}$ \\
\hline Shelter Services & 263 & 6 & 1,621 & 4 & 2.553 \\
\hline Housing & 324 & 8 & 2,180 & 6 & 2.189 \\
\hline Legal & 285 & 7 & 2,606 & 7 & 0.060 \\
\hline Child Victim Support Services & 239 & 6 & 2,655 & 7 & 0.374 \\
\hline Recreational Services & 250 & 6 & 1,383 & 4 & 3.339 \\
\hline Special Education Placement & - & - & 401 & 1 & 1.716 \\
\hline Medical/Dental Services & 234 & 6 & 2,275 & 6 & 0.011 \\
\hline Child/Day Care & 339 & 8 & 1,542 & 4 & $7.642^{* *}$ \\
\hline Speech/Language Services & - & - & 462 & 1 & 0.186 \\
\hline Cultural Services & 738 & 18 & 1,200 & 3 & $91.990^{* * *}$ \\
\hline Immigration Services & 420 & 10 & 204 & 1 & $116.561^{* * *}$ \\
\hline No Referral Made & 6,448 & 61 & 69,798 & 64 & \\
\hline At Least One Referral Made & 4,143 & 40 & 39,644 & 36 & \\
\hline Total & 10,591 & 100 & 109,442 & 100 & \\
\hline
\end{tabular}

Note. Based on an unweighted sample of 515 Newcomer households and 6,675 non-Newcomer households.

Rate and percentage columns of the type of referral made do not add to totals because investigating workers could make more than one referral. - indicates the estimate was $<100$ referrals.

${ }^{*} p \leq .05^{* *} p \leq .01{ }^{* * *} p \leq .001$.

Maltreatment and Risk Investigations. In Newcomer families, the primary maltreatment-related concerns investigated were: risk of future maltreatment (34\%), physical abuse (27\%), exposure to intimate partner violence (24\%), neglect (11\%), emotional maltreatment (2\%), and sexual abuse (2\%). In comparison, the primary maltreatment-related concerns for non-Newcomer families were: risk of future maltreatment (37\%), physical abuse (20\%), exposure to intimate partner violence (19\%), neglect (14\%), emotional maltreatment (7\%), and sexual abuse (3\%). The differences in the rates of the primary maltreatment-related concerns were statistically significant ( $p \leq .001)$.

In 51\% of maltreatment investigations with Newcomer families, the worker indicated that the concern was unfounded, and the child was not a victim of maltreatment. In maltreatment investigations with non-Newcomer families, the concerns were unfounded $54 \%$ of the time. In $41 \%$ of maltreatment investigations with Newcomer families, the worker concluded that the concern was substantiated, and the child was a victim of abuse or neglect. Forty percent of maltreatment investigations led to a substantiated concern in non-Newcomer families. Finally, in $9 \%$ of maltreatment investigations with Newcomer families, the worker suspected the child was a victim but did not have enough evidence to conclude the maltreatment occurred. Suspected maltreatment occurred in $6 \%$ of non-Newcomer maltreatment investigations. Differences in substantiation (substantiated, suspected, or unfounded) were not statistically significant between Newcomer and non-Newcomer families.

In risk-only investigations, $83 \%$ of workers indicated that investigated child from a Newcomer household was not at significant risk of future maltreatment. In $8 \%$ of risk-only investigations in Newcomer households, the worker stated that the child was at significant risk of future maltreatment. Finally, in $9 \%$ of risk-only investigations, the worker indicated that the child's significant risk of future maltreatment was unknown in Newcomer families. In non-Newcomer 
households, the worker indicated that $77 \%$ of children were not at significant risk of future maltreatment, and $16 \%$ were at significant risk of future maltreatment. These differences were statistically significant $(p \leq .001)$.

Ongoing Services and Placements. In 17\% of investigations with Newcomer families, the worker indicated that the file would transfer to ongoing services. In non-Newcomer investigations, 19\% of families were transferred to ongoing services. The difference was not statistically significant.

Notably, there was no difference between placement rates in child maltreatment-related investigations for children from Newcomer versus children from non-Newcomer households. In both groups, 97\% of children remained in the home, and only $3 \%$ were placed in out-of-home care.

\section{Discussion}

This study defined a child as being from a Newcomer household when at least one caregiver was identified as immigrated to Canada within five years. The definition allowed for a more comprehensive understanding of children of newcomers' experiences, as either parent's experiences may impact the child (Dennis et al., 2016; Greenberg, 2014; Hagelskamp et al., 2010; Hernandez \& Darke, 1999). The Population-based Disparity Index (PDI) suggests that children in a Newcomer household are approximately 2.48 times more likely to be investigated by child welfare than children in a non-Newcomer household. Significant findings from the bivariate analyses could explain possible reasons for this disparity and indicate priority areas for child welfare agencies to support their Newcomer families.

Children from Newcomer households may be at an increased risk for child maltreatment-related investigations due to vulnerabilities related to their migration, such as difficulties securing employment and housing and lack of proficiency in the new country's language (Pine \& Drachman, 2005). While the ranking of the primary type of investigated maltreatment-related concern is the same in the Newcomer and Non-Newcomer subsamples, and in the OIS-2018 sample, the rate between the Newcomer and non-Newcomer subsamples was statistically significant (Fallon et al., 2020). This could be explained by a few vulnerabilities. The majority (62\%) of primary caregivers for children in Newcomer households do not speak English as their primary language. As a result, there may be communication errors between newcomers, their community and child welfare service providers (Lee, 2016; Scheppers et al., 2006). Approximately a quarter (23\%) of the Canadian population reports a mother tongue language other than the official national languages of English and French (Statistics Canada, 2017c). Furthermore, according to the 2016 Canadian Census data, 7.3 million Canadians spoke an "immigrant language" at home (Statistics Canada, 2017c). Immigrant languages exclude "Aboriginal" and sign languages and are defined as languages other than English and French, whose existence in Canada originated due to immigration following English and French colonization (Statistics Canada, 2017c). Challenges in communication between newcomer caregivers and social service providers may result in unidentified caregiver risk factors and missed opportunities for social support (Sakamoto, 2007).

These vulnerabilities may also be related to a lack of social supports newcomer families experience during immigration, increasing the risk of child maltreatment behaviours (Barth, 2005; Drake \& Rank, 2009; Drake et al., 2011). Having few social supports was the most common caregiver risk factor in Newcomer households (39\%) identified in this study and was significantly more noted than in non-Newcomer households. This is particularly relevant given that Newcomer families have moved to Canada within five years of the investigation and may have few support networks in the country.

Workers noted that $24 \%$ of caregivers for children from non-Newcomer households had mental health issues, while only half that amount (12\%) of caregivers from Newcomer households were identified as having mental health issues as a caregiver risk factor. Subsequently, $24 \%$ of non-Newcomer families received referrals for psychiatric and mental health services following child maltreatment-related investigations, compared to 11\% of Newcomer families. This may indicate that mental health issues occur less frequently, and less support is needed in Newcomer communities. However, a more likely explanation could be that during child maltreatment-related investigations in Newcomer households, such concerns may not be disclosed or may not be determined by the social worker (Leong \& Lau, 2001; Lee, Fuller-Thomson, Fallon, Black, \& Trocmé, 2017). This may be due to communication challenges in identifying mental health issues and differences in cultural norms of disclosing mental health concerns (Leong \& Lau, 2001; Sakamoto, 2007). A scoping review concluded that Canadian immigrants underutilize mental health supports due to barriers to accessing services, barriers related to their immigration and an "inadequacy of culturally and linguistically appropriate services" (Tomson et al., 2015, p. 1897). An under-identification could leave newcomer families lacking needed supports and children from newcomer households at an increased vulnerability. Findings from this 
study indicate significant differences between caregiver risk factors in Newcomer and non-Newcomer. These findings can be used to tailor programs to meet the identified needs of newcomer families (Fallon et al., 2013).

The overrepresentation of children from Newcomer households may indicate discrimination, racism and systematic biases in child welfare services and policies (Antwi-Boasiako et al., 2020; Derezotes et al., 2005; Drake et al., 2011; Roberts, 2002). Nationally, Arab families are underrepresented in the child welfare population (Lavergne et al., 2008). However, when examining the Newcomer population, Arab families are the most investigated for child maltreatment-related concerns and among the least investigated in the non-Newcomer population. This may indicate that subpopulations of newcomers face unique stressors, resulting in identification to child welfare. The Black ethnoracial population, one of the highest disparity of cases identified for maltreatment concerns in Ontario (Fallon et al., 2016; OHRC, 2018), is also one of the most represented ethno-racial groups amongst Newcomers to be investigated. While this overrepresentation is well-known, child welfare workers continually lack training on ethnocultural diversity (Cénat, Noorishad et al., 2020). Significantly, following a systematic review of the literature, Cénat and colleagues concluded that racial biases accounted for the "most important risk factor" leading to overrepresentation (Cénat, Mclntee et al., 2020, p.13). Child welfare agencies must ensure policies and training actively address anti-racist practices (Cénat, Mclntee et al., 2020).

Many complexities are involved in the factors that influence the threshold for action and reporting an investigation (Dettlaff et al., 2011). Newcomer households (83\%) were significantly more likely to be referred to child welfare by a professional in the community, compared to non-Newcomer households (72\%). In Ontario, professionals have a legal duty to report if they suspect a child is being maltreated or is at risk of maltreatment (MCCSS, 2018). Newcomer families were noted to have few social supports more often than non-Newcomer families and may interact more often with professionals who are more likely to assess risk factors and are obligated to report concerns (Drake et al., 2011). Research on cultural family values, such as filial piety, has been shown to influence children's decision to disclose maltreatment prior to professional involvement (Lee, Fuller-Thomson, Fallon, Trocmé, \& Black, 2017).

Several methodological decisions were made during this study, which can create challenges for comparing this study to other research. Studies' methodological considerations and limitations must be understood to avoid indiscriminate interpretations of research outcomes that may lead to biased policy or practice decisions (Lee, 2016). These results should be examined as descriptive and require further investigation to understand their causes (Fluke et al., 2010). Further research of child maltreatment-related investigations of children from Newcomer households, including decision-based disparity, should be completed to avoid misinterpretations.

\section{Limitations}

The limitations of the OIS-2018 must be noted when analyzing and interpreting the data (Fallon et al., 2020). The OIS-2018 captures child maltreatment-related concerns that were investigated during a three-month period. The sample period was chosen in consultation with participating agencies as the "optimum period" as investigations during this time were "considered to be typical of a whole year" (Fallon et al., 2020, p. 19). However, a recent review of multiyear administrative child welfare data across five Canadian provinces and one territory revealed that during October to December, sexual abuse and neglect were less likely to occur, and physical abuse and emotional maltreatment were more likely to occur, compared to the first three quarters of the year (Shields et al., 2021).

OIS-2018 does not include incidents of child maltreatment that were not reported to child welfare authorities, screened out or not investigated by child welfare. New reports on cases already open are also not included in the sample. The OIS-2018 is a cross-sectional study and does not allow for causal or longitudinal interpretations. Data were collected based on child welfare workers' assessments and knowledge during their investigation for child maltreatment-related concerns and were not independently verified. Finally, the weighting procedures are based on annual estimates, which "include counts of children investigated more than once during the year" resulting in weighted estimates for child investigations (Fallon et al., 2020, p. 23). In some analyses, the sample sizes were too small to derive publishable estimates (e.g., Table 3 presents the ethno-racial background of non-Newcomer households, and a few categories could not be reported).

Within the current study, the identity of whether a caregiver was a Newcomer may not have been identified by the caregiver themselves but concluded by the child welfare worker. The current analyses did not use investigations where the worker selected "unknown" for all the caregivers in the home. Additionally, within this study Newcomers are a heterogeneous group. Acknowledging that Newcomers are composed of a diverse group, representative of multiple ethno-racial, religious, language and other backgrounds, this study aims to understand any disparities, vulnerabilities 
and risk factors this demographic may face given the shared experience of recently migrating to Canada.

Finally, Canadian Census data on recent migrants, which was used as our proxy for Newcomers, is collected every five years and most recently in 2016. It is anticipated that there are slight variations between the Census 2016 data and the 2018 population, the year the OIS-2018 data was collected. However, utilizing the 2016 Census data allowed for estimated population-based calculations.

\section{Conclusion}

The Population-based Disparity Index (PDI) calculations indicated that child maltreatment-related investigations for children from Newcomer households are approximately 2.48 times more likely to occur when compared to investigations for children from non-Newcomer households. There are significant differences in the referral source, identified maltreatment-related concerns, and caregiver risk factors for Newcomer households compared to non-Newcomer households. These results demonstrate a need for increased collaboration with newcomer communities and their social service providers to better understand risk factors of child welfare involvement, and to increase protective factors for children from newcomer families. As the newcomer population is not homogenous, community-informed research is critical for effective interventions and may lend itself to supporting other communities disproportionally represented in child welfare. Building on these results, future research should examine newcomers' interactions with child welfare after more extended settlement periods, including strengths these families build over time. Finally, multi-generational studies should examine second-generation parents' experiences with child welfare and longer-term outcomes for newcomer families.

\section{Funding}

The manuscript was completed with financial support from Dr. Barbara Fallon's Social Sciences and Humanities Research Council Canada Research Chair in Child Welfare (\#950-231186).

\section{Conflict of interest}

The authors have no conflict of interest to disclose.

\section{References}

Antwi-Boasiako, K., King, B., Fallon, B., Trocme, N., Fluke, J., Chabot, M., \& Esposito, T. (2020). Differences and disparities over time: Black and White families investigated by Ontario's child welfare system. Child Abuse \& Neglect, 107, Article 104618. https://doi.org/10.1016/j.chiabu.2020.104618

Barth, R. P. (2005). Child welfare and race: Models of disproportionality. In D. Derezotes, M. Testa, \& J. Poertner (Eds.). Race matters in child welfare: The overrepresentation of African American children in the system (pp. 25-46). Child Welfare League of America.

Beiser, M., Dion, R., Gotowiec, A., Hyman, I., \& Vu, N. (1995). Immigrant and refugee children in Canada. The Canadian Journal of Psychiatry, 4O(2), 67-72. https://doi.org/10.1177/070674379504000203

Cénat, J. M., Mclntee, S. E., Mukunzi, J. N., \& Noorishad, P. G. (2020). Overrepresentation of Black children in the child welfare system: A systematic review to understand and better act. Children and Youth Services Review, 120, Article 105714. https://doi.org/10.1016/j.childyouth.2020.105714

Cénat, J. M., Noorishad, P. G., Czechowski, K., McIntee, S. E., \& Mukunzi, J. N. (2020). Racial disparities in child welfare in Ontario (Canada) and training on ethnocultural diversity: An innovative mixed-methods study. Child Abuse \& Neglect, 108, Article 104659. https://doi.org/10.1016/j.chiabu.2020.104659

Critelli, F. M. (2015). Parenting in a new land: Specialized services for immigrant and refugee families in the USA. Journal of International Migration and Integration, 16(4), 871-890. https://doi.org/10.1007/s12134-014-0359-z

Child, Youth and Family Services Act, 2017, S.O. 2017, c. 14, Sched. 1. https://www.ontario.ca/laws/statute/17c14

Dennis, C. L., Merry, L., Stewart, D., \& Gagnon, A. J. (2016). Prevalence, continuation, and identification of postpartum depressive symptomatology among refugee, asylum-seeking, non-refugee immigrant, and Canadian-born women: Results from a prospective cohort study. Archives of Women's Mental Health, 196), 959-967. https://doi.org/10.1007/s00737-016-0633-5

Derezotes, D., Testa, M., \& Poertner, J. (Eds.). (2005). Race matters in child welfare: The overrepresentation of African American children in the system. Child Welfare League of America.

Dettlaff, A. J., Rivaux, S. L., Baumann, D. J., Fluke, J. D., Rycraft, J. R., \& James, J. (2011). Disentangling substantiation: The influence of race, income, and risk on the substantiation decision in child welfare. Children and Youth Services Review, 33(9), 1630-1637. 
http://doi.org/10.1016/j.childyouth.2011.04.005

Drake, B., Jolley, J. M., Lanier, P., Fluke, J., Barth, R. P., \& Jonson-Reid, M. (2011). Racial bias in child protection? A comparison of competing explanations using national data. Pediatrics, 123(3), 471-478. https://doi.org/10.1542/peds.2010-1710

Drake, B., Lee, S. M., \& Jonson-Reid, M. (2009). Race and child maltreatment reporting: Are Blacks overrepresented? Children and Youth Services Review, 37(3), 309-316. http://doi.org/10.1016/j.childyouth.2008.08.004

Drake, B. \& Rank, M. R. (2009). The racial divide among American children in poverty: Reassessing the importance of neighborhood. Children and Youth Services Review, 31(12), 1264-1271. http://doi.org/10.1016/j.childyouth.2009.05.012

Earner, I. (2007). Immigrant families and public child welfare: barriers to services and approaches for change. Child Welfare: Journal of Policy, Practice, and Program, 86(4), 63-91.

Fallon, B., Filippelli, J., Joh-Carnella, N., Miller, S. \& Denburg, A. (2019). Trends in investigations of abuse or neglect referred by hospital personnel in Ontario. BMJ Paediatrics Open, 3, Article e000386. https://doi.org/10.1136/bmjpo-2018-000386

Fallon, B., Filippelli, J., Lefebvre, R., Joh-Carnella, N., Trocme, N., Black, T., MacLaurin, B., Helie, S., Morin, Y., Fluke, J., King, B., Esposito, T., Collin-Vezina, D., Allan, K., Houston, E., Harlick, M., Bonnie, N., Budau, K., Goodman, D., ... Stoddart, J. (2020). Ontario incidence study of reported child abuse and neglect-2018 (OIS-2018). Child Welfare Research Portal. https://cwrp.ca/sites/default/files/publications/Ontario\%20Incidence\%20Study\%20of\%20Reported\%20Child\%20Abuse\%20an d\%20Neglect\%202018.pdf

Fallon, B., Ma, J., Allan, K., Pillhofer, M., Trocmé, N., \& Jud, A. (2013). Opportunities for prevention and intervention with young children: lessons from the Canadian incidence study of reported child abuse and neglect. Child and Adolescent Psychiatry and Mental Health, 7, Article 4. https://doi.org/10.1186/1753-2000-7-4

Fallon, B., Van Wert, M., Trocmé, N., MacLaurin, B., Sinha, V., Lefebvre, R., Allan, K., Black, T., Lee, B., Rha, W., Smith, C., \& Goel, S. (2015) Ontario incidence study of reported child abuse and neglect-2013 (OIS-2013). Child Welfare Research Portal. https://cwrp.ca/sites/default/files/publications/ois-2013_final_0.pdf

First Nations Information Governance Centre. (n.d.). The First Nations Principles of OCAP. https://fnigc.ca/ocap-training/

Fluke, J., Harden, B. J., Jenkins, M., \& Ruehrdanz, A. (2010). Research synthesis on child welfare disproportionality and disparities. In P. McCarthy (Ed.). Disparities and Disproportionality in child welfare: Analysis of the research. Center for the Study of Social Policy and The Annie E. Casey Foundation on behalf of the Alliance for Racial Equity in Child Welfare. https://www.acf.hhs.gov/sites/default/files/documents/cb/es2011_session_104.pdf

Garcini, L., Chen, N., Cantu, E., Sanchez, N., Ziauddin, K., Maza, V., \& Molina, M. (2020). Protective factors to the wellbeing of undocumented Latinx immigrants in the United States: A socio-ecological approach. Journal of Immigrant \& Refugee Studies. Advance online publication. https://doi.org/10.1080/15562948.2020.1836300

Greenberg, J. P. (2014). Significance of after-school programming for immigrant children during middle childhood: Opportunities for school social work. Social Work, 59(3), 243-251. https://doi.org/10.1093/sw/swu022

Hagelskamp, C., Suárez-Orozco, C., \& Hughes, D. (2010). Migrating to opportunities: How family migration motivations shape academic trajectories among newcomer immigrant youth. Journal of Social Issues, 66(4), 717-739. https://doi.org/10.1111/j.1540-4560.2010.01672.x

Hernandez, D., \& Darke, K. (1999). Socioeconomic and demographic risk factors and resources among children in immigrant and native-born families: 1910, 1960, and 1990. In D. Hernandez (Ed.), Children of immigrants: Health, adjustment, and public assistance (pp. 19-126). National Academy Press.

Human Rights Code, R.S.O. 1990, c. H.19. https://www.ontario.ca/laws/statute/90h19

International Organization for Migration (IOM). (2019). International migration law: Glossary on migration. https://publications.iom.int/system/files/pdf/iml_34_glossary.pdf

Johnson, M. A. (2007). The social ecology of acculturation: Implications for child welfare services to children of immigrants. Children and Youth Services Review, 29(11), 1426-1438. https://doi.org/10.1016/j.childyouth.2007.06.002

King, B., Fallon, B., Boyd, R., Black, T., Antwi-Boasiako, K., \& O'Connor, C. (2017). Factors associated with racial differences in child welfare investigative decision-making in Ontario, Canada. Child Abuse \& Neglect, 73, 89-105. https://doi.org/10.1016/j.chiabu.2017.09.027

Lavergne, C., Dufour, S., Trocmé, N., \& Larrivée, M. C. (2008). Visible minority, Aboriginal, and Caucasian children investigated by Canadian protective services. Child Welfare: Journal of Policy, Practice, and Program, 87(2), 59-76.

Lee, B., Fuller-Thomson, E., Fallon, B., Black, T., \& Trocmé, N. (2017). Examining child welfare decisions and services for Asian-Canadian versus White-Canadian children and families in the child welfare system. Child Maltreatment, 22(2), 132-144. https://doi.org/10.1177/1077559517690829

Lee, B., Fuller-Thomson, E., Fallon, B., Trocmé, N. \& Black, T. (2017). Asian-Canadian children and families involved in the child welfare 
system in Canada: A mixed methods study. Child Abuse \& Neglect, 70, 342-355. https://doi.org/10.1016/j.chiabu.2017.06.022

Lee, B., Fuller-Thomson, E., Trocmé, N., Fallon, B. \& Black, T. (2016). Delineating disproportionality and disparity of Asian-Canadian versus White-Canadian families in the child welfare system. Children and Youth Services Review, 70, 383-393. https://doi.org/10.1016/j.childyouth.2016.10.023

Leong, F. T. L., \& Lau, A. S. L. (2001). Barriers to providing effective mental health services to Asian Americans. Mental Health Services Research, 3(4), 201-214. http://doi.org/10.1023/A:1013177014788

Ministry of Children, Community and Social Services (MCCSS). (2018). Reporting child abuse and neglect: It's your duty. http://www.children.gov.on.ca/htdocs/English/childrensaid/reportingabuse/abuseandneglect.aspx

Nesteruk, O., \& Marks, L. D. (2011). Parenting in immigration: Experiences of mothers and fathers from Eastern Europe raising children in the United States. Journal of Comparative Family Studies, 42(6), 809-825. https://doi.org/10.3138/jcfs.42.6.809

Ontario Association of Children's Aid Societies (OACAS). (2020). Who we are: Mission. http://www.oacas.org/who-we-are/mission/

Ontario Human Rights Commision (OHRC). (2018). Interrupted childhoods: Over-representation of Indigenous and Black children in Ontario child welfare. http://www.ohrc.on.ca/en/interrupted-childhoods

Pine, B. A., \& Drachman, D. (2005). Effective child welfare practice with immigrant and refugee children and their Families. Child Welfare: Journal of Policy, Practice, and Program, 84(5), 537-562.

Roberts, D. (2002). Shattered bonds: The color of child welfare. Basic Books.

Rodriguez, S. (2019). "We're building the community; it's a hub for democracy.": Lessons learned from a library-based, school-district partnership and program to increase belonging for newcomer immigrant and refugee youth. Children and Youth Services Review, 102,135-144. https://doi.org/10.1016/j.childyouth.2019.04.025

Sakamoto, I. (2007). A critical examination of immigrant acculturation: Toward an anti-oppressive social work model with immigrant adults in a pluralistic society. British Journal of Social Work, 373), 515-535. https://doi.org/10.1093/bjsw/bcm024

Scheppers, E., van Donge, E., Dekker, J., Geertzen, J., \& Dekker, J. (2006). Potential barriers to the use of health services among ethnic minorities: A review. Family Practice, 23(3), 325-348. http://doi.org/10.1093/fampra/cmi113

Shields, M., Tonmyr, L., Morin, Y., Hovdestad, W., Adams, N., Esposito, T., Jervis, L., Maclsaac, S., Pang, C., Peterson, M., Thompson, D., Chabot, M., \& Trocmé, N. (2021). Testing for seasonality in Canadian child welfare investigations. Children and Youth Services Review, 122, Article 105878. https://doi.org/10.1016/j.childyouth.2020.105878

Segal, U. A., \& Mayadas, N. S. (2005). Assessment of issues facing immigrant and refugee families. Child Welfare: Journal of Policy, Practice, and Program, 84(5), 563-583.

Statistics Canada. (2010). Canada's Ethnocultural Mosaic, 2006 Census: Definitions. Statistic Canada catalogue no. 97-562XIE2006001. https://www12.statcan.gc.ca/census-recensement/2006/as-sa/97-562/note-eng.cfm

Statistics Canada. (2013). Canada's total population estimates, 2013. Statistics Canada catalogue no. 11-001-X. https://www150.statcan.gc.ca/n1/en/daily-quotidien/130926/dq130926a-eng.pdf?st=yTUZn3BW

Statistics Canada. (2017a). Children with an immigrant background: Bridging cultures. Statistics Canada catalogue no. 98-200X2016015. https://www12.statcan.gc.ca/census-recensement/2016/as-sa/98-200-x/2016015/98-200-x2016015-eng.pdf

Statistics Canada. (2017b). Immigration and ethnocultural diversity: Key results from the 2016 Census. Statistics Canada catalogue no. 11-001-X. https://www150.statcan.gc.ca/n1/en/daily-quotidien/171025/dq171025b-eng.pdf?st=F8YsOKUT

Statistics Canada. (2017c). An increasingly diverse linguistic profile: Corrected data from the 2016 Census. Statistics Canada catalogue no. no. 11-001-X. https://www150.statcan.gc.ca/n1/en/daily-quotidien/170817/dq170817a-eng.pdf?st=giO0iVKe

Statistics Canada. (2017d). Ontario and Canada. Census Profile. 2016 Census. Statistics Canada Catalogue no. 98-316-X2016001. https://www12.statcan.gc.ca/census-recensement/2016/dp-pd/prof/index.cfm?Lang=E

Statistics Canada. (2018). Immigration and ethnocultural diversity in Canada. Catalogue no. 99-010-X2011001. https://www12.statcan.gc.ca/nhs-enm/2011/as-sa/99-010-x/99-010-x2011001-eng.cfm\#a4

Statistics Canada. (2019). Classification of admission category of immigrant. Catalogue no. 99-010-X2011001. https://www23.statcan.gc.ca/imdb/p3VD.pl?Function=getVD\&TVD=323293\&CVD=323294\&CLV=0\&MLV=4\&D=1

Stewart, M., Anderson, J., Beiser, M., Mwakarimba, E., Neufeld, A., Simich, L., \& Spitzer, D. (2008). Multicultural meanings of social support among immigrants and refugees. International Migration, 46(3), 123-159. https://doi.org/10.1111/j.14682435.2008.00464.x

Suárez-Orozco, C., Gaytán, F. X., Bang, H. J., Pakes, J., O'Connor, E., \& Rhodes, J. (2010). Academic trajectories of newcomer immigrant youth. Developmental Psychology, 46(3), 602-618. https://doi.org/10.1037/a0018201

Tomson, M. S., Chaze, F., George, U., \& Guruge, S. (2015). Improving immigrant populations' access to mental health services in Canada: a review of barriers and recommendations. Journal of Immigrant and Minority Health, 176), 1895-1905. 
https://doi.org/10.1007/s10903-015-0175-3

Trocmé, N., Fallon, B., Sinha, V., Van Wert, M., Kozlowski, A., \& MacLaurin, B. (2013). Differentiating between child protection and family support in the Canadian child welfare system's response to intimate partner violence, corporal punishment, and child neglect. International Journal of Psychology, 48(2), 128-140. https://doi.org/10.1080/00207594.2013.765571

Trocmé, N., Knoke, D., \& Blackstock, C. (2004). Pathways to the overrepresentation of Aboriginal children in Canada's child welfare system. Social Service Review, 78(4), 577-600. https://doi.org/10.1086/424545

Turner, T. (2016). One vision one voice: Changing the Ontario child welfare system to better serve African Canadians. Practice Framework Part 2: Race Equity Practices. Ontario Association of Children's Aid Societies. http://www.oacas.org/wpcontent/uploads/2016/09/One-Vision-One-Voice-Part-2_digital_english-May-2019.pdf 